\title{
Superior mesenteric artery occlusion as the manifestation of left atrial myxoma: an extremely rare occurrence
}

\author{
Kunal Mahajan, Sanjeev Asotra, Prakash Negi, Shivani Rao
}

Indira Gandhi Medical College, Shimla, Himachal Pradesh, India

\section{Correspondence to}

Dr Kunal Mahajan,

kunalmahajan442@gmail.com

Accepted 27 March 2016
CrossMark

To cite: Mahajan $\mathrm{K}$,

Asotra S, Negi P, et al. BMJ Case Rep Published online: [please include Day Month Year] doi:10.1136/bcr-2016215332

\section{DESCRIPTION}

A 62-year-old woman was presented to the surgical ward, with severe abdominal pain and vomiting. She had sinus tachycardia $(135 / \mathrm{min})$ and her blood pressure was $80 / 60 \mathrm{~mm} \mathrm{Hg}$. The physical examination revealed generalised abdominal distension with signs of peritonitis. Laboratory parameters revealed polymorphonuclear leucocytosis (total leucocyte count of $21000 / \mathrm{mm}^{3}$ with $88 \%$ neutrophils), blood urea nitrogen $=74 \mathrm{mg} / \mathrm{dL}$ and serum creatinine $=2.1 \mathrm{mg} / \mathrm{dL}$. X-ray of the abdomen showed air under the diaphragm. CT angiography revealed absence of contrast beyond the mid segment of the superior mesenteric artery (SMA) (figure 1). A large filling defect was noted in the left atrium (LA) on CT scan (figure 2). Echocardiogram also demonstrated a large $3.1 \times 3.2 \mathrm{~cm}$ rounded, mobile mass in the left atrium, which was heterogeneous in echogenicity (figure 3A). It was attached to the interatrial septum in the region of the fossa ovalis. The LA appendage was clear (figure 3B). Neither mitral valve nor left ventricle showed underlying disease.

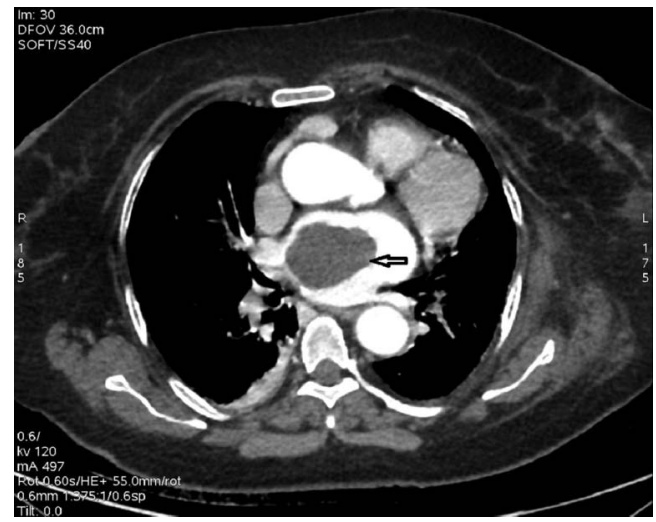

Figure 2 CT of the thorax showing a large filling defect in the left atrium (arrow).

These features were supportive of a diagnosis of cardiac myxoma, instead of a thrombus. Unfortunately, the condition of the patient continued to deteriorate and she succumbed to sepsis. Relatives refused an autopsy, so histopathological

Figure $1 \mathrm{CT}$ angiography showing absence of contrast beyond the mid segment of the superior mesenteric artery (arrow).

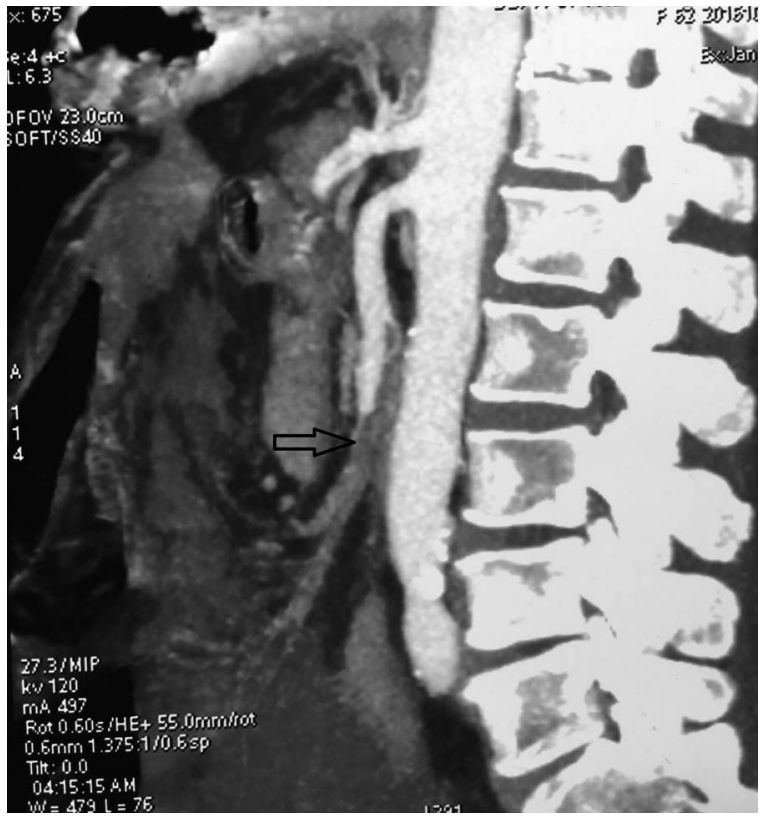


A B

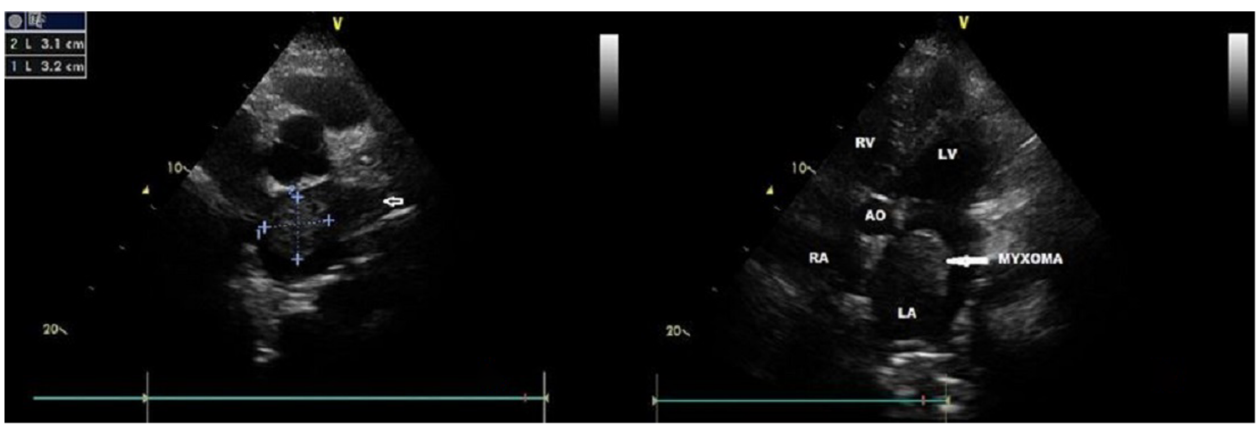

Figure 3 (A) Transthoracic echocardiogram, parasternal short axis view, showing a large $3.1 \times 3.2 \mathrm{~cm}$ rounded, heterogeneous echogenic mass in the left atrium. Note that the left atrial appendage is clear (white arrow). (B) Transthoracic echocardiogram, apical four-chamber view, showing the left atrial mass attached to the interatrial septum near the fossa ovalis. AO, aorta; LA, left atrium; LV, left ventricle; RA, right atrium; RV, right ventricle.

diagnosis was not possible. Myxomas are the most common primary tumours of the heart, and are often located in the LA, where they arise mostly from the interatrial septum. ${ }^{1}$

\section{Learning points}

- Cardiac myxoma is the most common benign cardiac tumour and has a high embolic potential.

- Mobility, location in the region of interatrial septum with sparing of left atrial appendage and heterogeneous echogenicity on imaging are some of the features favouring the diagnosis of myxoma rather than a thrombus.

- The most common site of embolisation is the central nervous system followed by the coronary, renal, mesenteric and peripheral arteries.

- Embolisation of cardiac myxoma to the superior mesenteric artery causing acute intestinal obstruction has rarely been reported.

- Besides myxoma, other cardiac tumours that have a high embolic potential include sarcoma, lipoma and fibroelastoma.
Embolisation occurs in 30-40\% of patients with myxomas, with cerebral arteries being the most common destination. Symptoms related to peripheral embolism are experienced in $2-15 \%$ of cases. Cases of mesenteric embolism are extremely rare. ${ }^{2}$ Retrospective studies have shown that histological cardiac tumour is an independent predictor of an embolic event. Besides myxoma, other tumours with high embolic potential are sarcoma, lipoma and fibroelastoma. ${ }^{3}$

Competing interests None declared.

Patient consent Obtained.

Provenance and peer review Not commissioned; externally peer reviewed.

\section{REFERENCES}

1 Ha J, Kang W, Chung N, et al. Echocardiographic and morphologic characteristics of left atrial myxoma and their relation to systemic embolism. Am J Cardiol 1999:83:1579-82.

2 Pérez Baztarrica G, Bornancini N, Salvaggio F, et al. An unsual case of mesenteric ischemia in a patient with cardiac myxoma. Rev Port Cardiol 2013;32: 609-12

3 Dias RR, Fernandes F, Ramires FJ, et al. Mortality and embolic potential of cardiac tumors. Arq Bras Cardiol 2014;103:13-18.

\footnotetext{
Copyright 2016 BMJ Publishing Group. All rights reserved. For permission to reuse any of this content visit http://group.bmi.com/group/rights-licensing/permissions.

BMJ Case Report Fellows may re-use this article for personal use and teaching without any further permission.

Become a Fellow of BMJ Case Reports today and you can:

- Submit as many cases as you like

- Enjoy fast sympathetic peer review and rapid publication of accepted articles

- Access all the published articles

- Re-use any of the published material for personal use and teaching without further permission

For information on Institutional Fellowships contact consortiasales@bmjgroup.com

Visit casereports.bmj.com for more articles like this and to become a Fellow
} 